\title{
Halomonas daqingensis sp. nov., a moderately halophilic bacterium isolated from an oilfield soil
}

\author{
Correspondence \\ Xiao-Lei Wu \\ xiaolei_wu@tsinghua.edu.cn \\ Ya-Nang Wang \\ wangyanan@mail.tsinghua.edu.cn
}

\author{
Gang Wu, ${ }^{1}$ Xiao-Oing Wu, ${ }^{1}$ Ya-Nan Wang, ${ }^{2}$ Chang-Qiao Chi, ${ }^{2}$ \\ Yue-Oin Tang, ${ }^{2}$ Kenji Kida, ${ }^{3}$ Xiao-Lei $\mathrm{Wu}^{2}$ and Zhao-Kun Luan ${ }^{1}$
${ }^{1}$ State Key Laboratory of Urban and Regional Ecology, Research Center for Eco-Environmental Sciences, Chinese Academy of Sciences, Beijing 100085, PR China
${ }^{2}$ Department of Energy and Resources Engineering, College of Engineering, Peking University, Beijing 100871, PR China \\ ${ }^{3}$ Department of Materials and Life Science, Graduate School of Science and Technology, \\ Kumamoto University, 2-39-1 Kurokami, Kumamoto City, Kumamoto 860-8555, Japan
}

\begin{abstract}
A Gram-negative, moderately halophilic, short rod-shaped, aerobic bacterium with peritrichous flagellae, strain DQD2-30', was isolated from a soil sample contaminated with crude oil from the Daqing oilfield in Heilongjiang Province, north-eastern China. The novel strain was capable of growth at $\mathrm{NaCl}$ concentrations of $1-15 \%(\mathrm{w} / \mathrm{v})$ [optimum at $5-10 \%(\mathrm{w} / \mathrm{v})$ ]. Phylogenetic analyses based on 16S rRNA gene sequences showed that the novel strain belonged to the genus Halomonas in the class Gammaproteobacteria; the highest 16S rRNA gene sequence similarities were with Halomonas desiderata DSM $9502^{\top}$ (98.8\%), Halomonas campisalis A4 ${ }^{\top}$ $(96.6 \%)$ and Halomonas gudaonensis CGMCC $1.6133^{\top}(95.1 \%)$. The major cellular fatty acids of strain DQD2-30 ${ }^{\top}$ were $\mathrm{C}_{18: 1} \omega 7 c(43.97 \%), \mathrm{C}_{19: 0}$ cyclo $\omega 8 c(23.37 \%)$ and $\mathrm{C}_{16: 0}(14.83 \%)$. The predominant respiratory lipoquinone was ubiquinone with nine isoprene units (Q9). The DNA G +C content was $67.0 \mathrm{~mol} \%$. The DNA-DNA hybridization values of strain DQD2-30 ${ }^{\top}$ with the most closely related species of the genus Halomonas were $51.8 \%, 28.4 \%$ and $23.5 \%$ for $H$. desiderata, $H$. campisalis and $H$. gudaonensis, respectively. Based on these analyses, strain DQD2-30 ${ }^{\top}$ (=CGMCC $1.6443^{\top}=$ LMG $23896^{\top}$ ) is proposed to represent the type strain of a novel species, Halomonas daqingensis sp. nov.
\end{abstract}

Members of the genus Halomonas can grow in a wide range of salt concentrations from 0 to $25 \%(\mathrm{w} / \mathrm{v})$ or even higher (Vreeland et al., 1980). In addition, Halomonas species possess diverse biochemical functions, such as exopolysaccharide production by Halomonas maura (Bouchotroch et al., 2001), Halomonas ventosae (Martínez-Cánovas et al., 2004a, c), Halomonas anticariensis (Martínez-Cánovas et al., 2004b) and Halomonas almeriensis (Martínez-Checa et al., 2005); polyhydroxybutyrate production by Halomonas pantelleriensis (Romano et al., 1996); degradation of aromatic compounds by Halomonas organivorans (García et al., 2004); denitrification by Halomonas elongata (Vreeland et al., 1980), Halomonas salina, Halomonas halodenitrificans (Dobson \& Franzmann, 1996), Halomonas desiderata (Berendes et al., 1996), Halomonas campisalis (Mormile et al., 1999), Halomonas neptunia, Halomonas

Abbreviations: DPG, diphosphatidylglycerol; EPS, exopolysaccharides; $\mathrm{PE}$, phosphatidylethanolamine; PG, phosphatidylglycerol; $\mathrm{PHB}$, poly- $\beta$ hydroxybutyrate.

The GenBank/EMBL/DDBJ accession number for the $16 \mathrm{~S}$ rRNA gene sequence of strain DQD2-30 ${ }^{\top}$ is EF121854. sulfidaeris, Halomonas axialensis, Halomonas hydrothermalis (Kaye et al., 2004) and H. maura (Bouchotroch et al., 2001), and $\mathrm{H}_{2} \mathrm{~S}$-production by $H$. salina, Halomonas halophila (Dobson \& Franzmann, 1996), H. maura (Bouchotroch et al., 2001) and H. sulfidaeris (Kaye et al., 2004). These diverse abilities have led to increasing interest in the members of the genus Halomonas as useful candidates for the bioremediation of polluted saline soils.

During research on effective microbial degradation of oil pollutants, we isolated a novel moderately halophilic, Gram-negative bacterium, strain DQD2-30 ${ }^{\mathrm{T}}$, that was able to grow in crude-oil contaminated soil. A taxonomic study based on a polyphasic approach revealed that strain DQD2-30 ${ }^{\mathrm{T}}$ represents a novel species in the genus Halomonas.

Strain DQD2-30 ${ }^{\mathrm{T}}$ was isolated from an oil-polluted soil sample from Daqing Oilfield, Heilongjiang Province, north-eastern China. It was initially cultured with oilproduction-water medium 2 (OPW2) containing $5 \mathrm{~g}$ peptone, $1 \mathrm{~g}$ yeast extract and $1 \mathrm{l} \mathrm{oil} /$ water mixture from the oil reservoir at $30{ }^{\circ} \mathrm{C}$. The novel strain was then grown 
and identified by using artificial seawater medium (ASW) containing: $5 \mathrm{~g}$ peptone, $1 \mathrm{~g}$ yeast extract, $4 \mathrm{~g} \mathrm{Na}_{2} \mathrm{SO}_{4}$, $0.68 \mathrm{~g} \mathrm{KCl}, 0.1 \mathrm{~g} \mathrm{KBr}, 0.025 \mathrm{~g} \mathrm{H}_{3} \mathrm{BO}_{3}, 5.4 \mathrm{~g} \mathrm{MgCl}_{2} . \mathrm{H}_{2} \mathrm{O}$, $1.5 \mathrm{~g} \mathrm{CaCl}_{2} .2 \mathrm{H}_{2} \mathrm{O}, 0.024 \mathrm{~g} \mathrm{SrCl}_{2} \cdot 6 \mathrm{H}_{2} \mathrm{O}, 0.2 \mathrm{~g} \mathrm{NaHCO}_{3}$, $0.04 \mathrm{~g} \mathrm{Na}_{2} \mathrm{HPO}_{4}, 0.5 \mathrm{~g} \mathrm{NH}_{4} \mathrm{Cl}, 0.002 \mathrm{~g} \mathrm{NaF}$ and $11 \mathrm{H}_{2} \mathrm{O}$ with $2.4 \%(\mathrm{w} / \mathrm{v}) \mathrm{NaCl}(\mathrm{pH} 8.0)$ (Eguchi et al., 1996).

After cells of strain DQD2- $30^{\mathrm{T}}$ had been grown on ASW plates at $30{ }^{\circ} \mathrm{C}$ for two days, cellular morphology was examined using transmission electron microscopy. The salt requirement for growth was tested with ASW medium with final $\mathrm{NaCl}$ concentrations of $1 \%, 5 \%, 10 \%, 15 \%, 20 \%$, $25 \%(\mathrm{w} / \mathrm{v})\left(\mathrm{pH} 8.0\right.$, at $\left.30{ }^{\circ} \mathrm{C}\right)$. The $\mathrm{pH}$ and temperature requirements for growth were determined by adjusting the final $\mathrm{pH}$ of the ASW medium to $\mathrm{pH} 2,4,6,7,8,10$ or 12 with $\mathrm{HCl}$ and $\mathrm{NaOH}\left(30{ }^{\circ} \mathrm{C}\right)$, and by incubation from $4{ }^{\circ} \mathrm{C}$ to $50{ }^{\circ} \mathrm{C}$ (at $4,10,15,25,30,37,40,45,50$ and $\left.55{ }^{\circ} \mathrm{C}\right)(5 \%$ $\mathrm{NaCl}, \mathrm{pH} 8.0$ ), respectively. Strain DQD2-30 ${ }^{\mathrm{T}}$ was Gramnegative and cells were short rods with peritrichous flagellae (Fig. 1). Colonies on ASW medium were creamy, circular and opaque. Strain DQD2-30 ${ }^{\mathrm{T}}$ was strictly aerobic and grew at $1-15 \%(\mathrm{w} / \mathrm{v}) \mathrm{NaCl}$ with optimum growth at 5-10\% (w/v) NaCl. Growth temperatures ranged from 10 to $50{ }^{\circ} \mathrm{C}$ in ASW medium ( $\mathrm{pH}$ 8.0) with optimum growth at $30{ }^{\circ} \mathrm{C}$. The $\mathrm{pH}$ range for growth was $\mathrm{pH} 8.0-10.0$ (optimum at $\mathrm{pH}$ 9.0) (Table 1).

The oxidase activity of strain DQD2- $30^{\mathrm{T}}$ was tested according to Smibert \& Krieg (1994) and catalase activity was determined by using $3 \%(\mathrm{v} / \mathrm{v})$ hydrogen peroxide solution (Dong \& Cai, 2001). Nitrite and nitrate reduction were tested in ASW medium by growing the strain in the

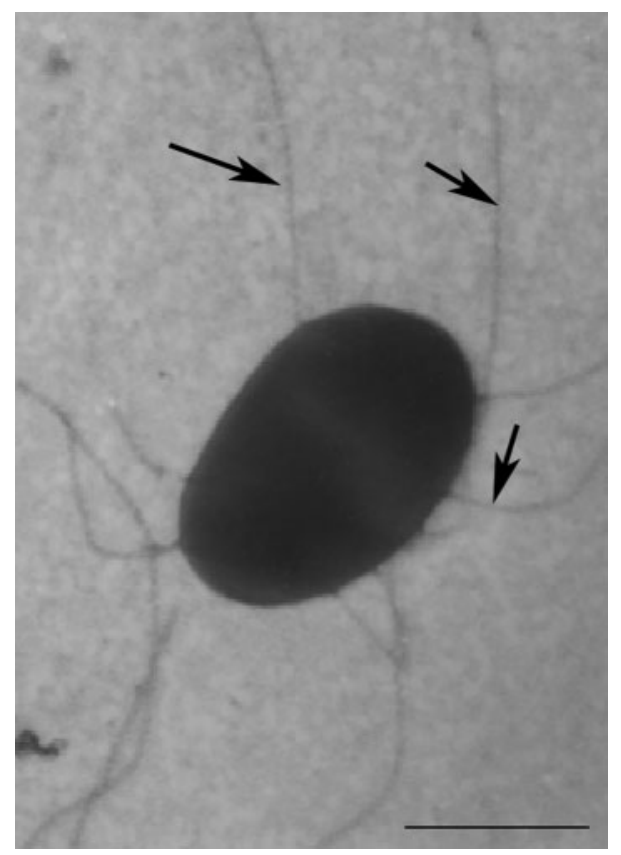

Fig. 1. Transmission electron micrograph of a negatively stained cell of strain DQD2-30'. Arrows show the flagellae. Bar, $0.5 \mu \mathrm{m}$. presence of $\mathrm{NO}_{2}^{-}$and $\mathrm{NO}_{3}^{-}$, respectively (Berendes et al., 1996). Denitrification was tested by growing the strain anaerobically in the presence of $\mathrm{NO}_{3}^{-}$(Zumft, 1992). Hydrolysis of starch, gelatin and Tween 80 , urease activity and growth on sole carbon and nitrogen sources were examined according to the procedures of Williams et al. (1983) on ASW medium without organic compounds at $30{ }^{\circ} \mathrm{C}$ for $5-7$ days. $\mathrm{H}_{2} \mathrm{~S}$ production was tested in ASW medium supplemented with $0.01 \%$ L-cysteine, the indicator being a strip of paper impregnated with lead acetate placed in the neck of the tube (Clarke, 1953; Mata et al., 2002). Methyl red and Voges-Proskauer tests were performed by using methyl red and Barritt's reagent (Barritt, 1936; Mata et al., 2002), respectively. Strain DQD2-30 ${ }^{\mathrm{T}}$ was subjected to the phenotypic tests according to the procedures recommended by Mata et al. (2002), including the production of exopolysaccharides (EPS) and poly- $\beta$-hydroxybutyrate (PHB), the production of acid from a range of different carbohydrates and alcohols, ONPG, indole production, oxidation/fermentation of Dglucose, the hydrolysis of casein and DNA, activities of phenylalanine deaminase, lysine- and ornithine decarboxylases, and the ability to grow on sole nitrogen sources.

Strain DQD2-30 ${ }^{\mathrm{T}}$ was positive for activities of oxidase, catalase and urease, for the hydrolysis of Tween 80 , casein and DNA, for aerobic nitrate or nitrite reduction, and for production of indole, EPS and PHB. The strain was negative in tests for $\mathrm{H}_{2} \mathrm{~S}$ production, ONPG, activities of phenylalanine deaminase, lysine decarboxylase and ornithine decarboxylase, the methyl red and VogesProskauer tests and for the hydrolysis of starch and gelatin. Strain DQD2-30 ${ }^{\mathrm{T}}$ could use the amino acids L-proline, Larginine, L-alanine, L-cysteine, L-histidine, L-isoleucine, Llysine, DL-methionine, L-serine and L-valine. Strain DQD2$30^{\mathrm{T}}$ was able to utilize D-glucose, D-mannose, D-sorbitol, maltose, sucrose, trehalose, dextrin, D-mannitol, D-gluconate, malonate, DL-malate, dextrin, D-galactose (weakly) and succinate as sole carbon sources in ASW medium without peptone and yeast extract, but was unable to utilize D-fructose, D-ribose, $\alpha$-D-lactose, D-arabinose, cellobiose, Lsorbose, D-xylose, myo-inositol, salicylic acid or lactate. Strain DQD2- $30^{\mathrm{T}}$ produced acid from D-galactose, maltose, sucrose, and trehalose, but not from adonitol, $\alpha$-Dlactose, D-mannitol, D-mannose, melezitose, L-rhamnose, D-sorbitol, D-fructose, L-sorbose, salicylic acid or myoinositol.

Genomic DNA was extracted according to the previously described method of Marmur (1961) from cells grown in ASW medium for 2 days at $30{ }^{\circ} \mathrm{C}$ that had been washed and resuspended in buffer. Purity of the DNA was assessed by the $A_{280} / A_{260}$ and $A_{230} / A_{260}$ ratios (Johnson, 1994). Phylogenetic analyses based on 16S rRNA gene sequences were performed as described by Bouchotroch et al. (2001). The 16S rRNA gene was amplified with universal bacterial primers corresponding to Escherichia coli position $8 \mathrm{~F}$ ( $5^{\prime}$ AGAGTTTGATCCTGGCTCAG) and 1492R (5'GGTTACCTTGTTACGACTT) (Embley, 1991). The $16 \mathrm{~S}$ 
Table 1. Physiological and biochemical characteristics that differentiate strain $D Q D 2-30^{\top}$ from closely related species of the genus Halomonas

Taxa: 1, DQD2-30 ${ }^{\mathrm{T}} ; 2$, H. gudaonensis; 3, H. desiderata; 4, H. campisalis. Data for carbon source utilization are from the present study and from Berendes et al. (1996), Mormile et al. (1999) and Wang et al. (2007). All strains are Gram-negative rods, that are positive in tests for catalase and oxidase and for the utilization of sucrose, trehalose, DL-malate, D-gluconate, D-sorbitol, succinate, L-proline, Larginine and L-alanine. All strains are negative for hydrolysis of gelatin and starch and for the utilization of D-ribose, D-arabinose, Dfructose, cellobiose, L-sorbose, D-xylose and lactate. -, Negative; +, positive; +/-, weakly positive; ND, not determined.

\begin{tabular}{|c|c|c|c|c|}
\hline Characteristic & 1 & 2 & 3 & 4 \\
\hline Cell size $(\mu \mathrm{m})$ & $0.7-0.8 \times 1.0-1.2$ & $0.3-4.0 \times 0.7-1.6$ & $0.4-0.6 \times 1.0-2.6$ & $1.0 \times 3-5$ \\
\hline Flagellation & Peritrichous & Single lateral & Peritrichous & Absent \\
\hline EPS & + & + & $\mathrm{ND}$ & $\mathrm{ND}$ \\
\hline PHB & + & ND & + & $\mathrm{ND}$ \\
\hline Optimum temperature $\left({ }^{\circ} \mathrm{C}\right)$ & 30 & 30 & 37 & 30 \\
\hline Temperature range $\left({ }^{\circ} \mathrm{C}\right)$ & $10-50$ & $10-42$ & $10-45$ & $4-50$ \\
\hline Optimum $\mathrm{pH}$ & 9.0 & 8.0 & 9.7 & 9.5 \\
\hline $\mathrm{pH}$ range & $8.0-10.0$ & $8.0-9.0$ & $7.0-11.0$ & $6.0-11.0$ \\
\hline Optimum $\mathrm{NaCl}(\%)$ & $5.0-10.0$ & $10.0-15.0$ & 9.0 & 8.0 \\
\hline $\mathrm{NaCl}$ range $(\%)$ & $1-15.0$ & $1.0-20.0$ & $1-18.0$ & $1.0-20.0$ \\
\hline Oxidation/fermentation of D-glucose & Oxidation & ND & $\mathrm{ND}$ & ND \\
\hline Hydrolysis of casein and DNA & + & ND & $\mathrm{ND}$ & $\mathrm{ND}$ \\
\hline ONPG & - & ND & $\mathrm{ND}$ & $\mathrm{ND}$ \\
\hline Indole production & + & - & - & - \\
\hline Phenylalanine deaminase & - & - & + & - \\
\hline Lysine decarboxylases & - & ND & $\mathrm{ND}$ & $\mathrm{ND}$ \\
\hline Ornithine decarboxylases & - & ND & ND & $\mathrm{ND}$ \\
\hline \multicolumn{5}{|l|}{ Growth on: } \\
\hline D-Glucose & + & + & + & $+1-$ \\
\hline D-Galactose & $+1-$ & + & $+1-$ & - \\
\hline Malonate & + & $+1-$ & + & $+1-$ \\
\hline myo-Inositol & - & $+1-$ & + & + \\
\hline D-Mannitol & + & + & + & $+1-$ \\
\hline Dextrin & + & $+1-$ & + & $+1-$ \\
\hline$\alpha$-D-Lactose & - & + & $+1-$ & - \\
\hline D-Mannose & + & + & + & - \\
\hline Maltose & + & + & + & - \\
\hline Salicylic acid & - & ND & $\mathrm{ND}$ & $\mathrm{ND}$ \\
\hline \multicolumn{5}{|l|}{ Hydrolysis of: } \\
\hline Urea & + & + & - & + \\
\hline Tween 80 & + & - & - & - \\
\hline Aerobic $\mathrm{NO}_{3}^{-}$reduction & + & + & $+1-$ & + \\
\hline Aerobic $\mathrm{NO}_{2}^{-}$reduction & + & $+1-$ & - & $+1-$ \\
\hline Anaerobic $\mathrm{NO}_{3}^{-}$reduction & - & + & + & - \\
\hline $\mathrm{H}_{2} \mathrm{~S}$ production & - & + & - & - \\
\hline \multicolumn{5}{|l|}{ Growth on: } \\
\hline L-Cysteine & + & + & $\mathrm{ND}$ & $\mathrm{ND}$ \\
\hline L-Histidine & $+1-$ & ND & $\mathrm{ND}$ & $\mathrm{ND}$ \\
\hline L-Isoleucine & + & + & ND & ND \\
\hline L-Lysine & + & - & $\mathrm{ND}$ & $\mathrm{ND}$ \\
\hline DL-Methionine & + & ND & ND & ND \\
\hline L-Serine & + & $\mathrm{ND}$ & $\mathrm{ND}$ & $\mathrm{ND}$ \\
\hline L-Valine & + & ND & $\mathrm{ND}$ & ND \\
\hline \multicolumn{5}{|l|}{ Production of acid from } \\
\hline Adonitol & - & ND & ND & ND \\
\hline D-Galactose & + & - & $\mathrm{ND}$ & - \\
\hline Lactose & - & - & ND & - \\
\hline Maltose & + & - & ND & $\mathrm{ND}$ \\
\hline Mannitol & - & + & ND & ND \\
\hline $\mathrm{D}-(+)$-Mannose & - & - & ND & ND \\
\hline
\end{tabular}


Table 1. cont.

\begin{tabular}{|lcccc|}
\hline Characteristic & $\mathbf{1}$ & $\mathbf{2}$ & $\mathbf{3}$ & $\mathbf{4}$ \\
\hline Melezitose & - & - & $\mathrm{ND}$ & $\mathrm{ND}$ \\
L-Rhamnose & - & - & $\mathrm{ND}$ & - \\
Sucrose & + & - & $\mathrm{ND}$ & $\mathrm{ND}$ \\
D-Sorbitol & - & + & $\mathrm{ND}$ & $\mathrm{ND}$ \\
Trehalose & + & - & ND & ND \\
\hline
\end{tabular}

rRNA gene sequence of strain DQD2-30 ${ }^{\mathrm{T}}$ was compared with those available in GenBank using the BLAST program (NCBI) to determine the approximate phylogenetic affiliation. The $16 \mathrm{~S}$ rRNA gene sequence of strain DQD2-30 ${ }^{\mathrm{T}}$ was aligned with related species of the genus Halomonas and phylogenetic trees were constructed using the neighbour-joining, maximum-parsimony and maximumlikelihood methods in the MEGA software (Kumar et al., 2004). The genomic DNA G + C content of strain DQD2$30^{\mathrm{T}}$ was estimated from the midpoint value $\left(T_{\mathrm{m}}\right)$ of the thermal denaturation profile, as described by MartínezCánovas et al. (2004b). DNA-DNA hybridization of strain DQD2 $-30^{\mathrm{T}}$ was performed in triplicate following the methods of De Ley et al. (1970) and Huß et al. (1983). It was performed with strain DQD2-30 ${ }^{\mathrm{T}}$ and the most closely related strains, $H$. desiderata DSM $9502^{\mathrm{T}}, H$. campisalis $\mathrm{A}^{\mathrm{T}}{ }^{\mathrm{T}}$ and H. gudaonensis LMG $23610^{\mathrm{T}}$.

The DNA G+C content of strain DQD2- $30^{\mathrm{T}}$ was $67.0 \mathrm{~mol} \%$, within the range of $52-68 \mathrm{~mol} \%$ that has already been reported for the genus Halomonas (Franzmann \& Tindall, 1990). The nearly complete 16S rRNA gene sequence (1422 bp) of strain DQD2-30 ${ }^{\mathrm{T}}$ was determined and analysed. The results revealed that strain DQD2- $30^{\mathrm{T}}$ was a member of the genus Halomonas and had close phylogenetic relationships with $H$. desiderata DSM 9502 ${ }^{\mathrm{T}}$ (Berendes et al., 1996), H. campisalis $\mathrm{A}^{\mathrm{T}}$ (Mormile et al., 1999) and H. gudaonensis LMG $23610^{\mathrm{T}}$ (Wang et al., 2007) with 16S rRNA gene sequence similarity values of $98.8 \%, 96.6 \%$ and $95.1 \%$, respectively. A phylogenetic tree was constructed and it clearly showed the position of strain DQD2- $30^{\mathrm{T}}$ within the genus Halomonas, with the novel strain forming a cluster with $H$. campisalis, $H$. desiderata and H. gudaonensis (Fig. 2). Further DNA-DNA hybridization experiments between strain DQD2-30 ${ }^{\mathrm{T}}$ and $H$. desiderata, $H$. campisalis and $H$. gudaonensis revealed that the DNA-DNA relatedness values were $51.8 \pm 0.05 \%$, $28.41 \pm 0.06 \%$ and $23.47 \pm 0.06 \%$, respectively.

The chemotaxonomic study of strain DQD2-30 ${ }^{\mathrm{T}}$ included analysis of the cellular fatty acids, polar lipids and quinones. Cellular fatty acid analysis was carried out as described by Komagata \& Suzuki (1987) and tested using GC/MS following the instructions of the Microbial Identification System (MIDI). Polar lipid analysis was performed following the polar lipid extraction procedure and tested by single and two-dimensional TLC on Merck silica gel 60 F254 aluminium-backed TLC plates according to the methods of Kates (1986) and Collins et al. (1980).
Isoprenoid quinones were analysed as described by Komagata \& Suzuki (1987) and using an HPLC fitted with a reversed-phase column (Shim-pack, VP-ODS, Shimadzu). Ubiquinone 9 was the only quinone found and the predominant polar lipids found in cells of strain DQD2-30 ${ }^{\mathrm{T}}$ were phosphatidylglycerol (PG), diphosphatidylglycerol (DPG) and phosphatidylethanolamine (PE). The main cellular fatty acids were $\mathrm{C}_{18: 1} \omega 7 c(43.97 \%)$, $\mathrm{C}_{19: 0}$ cyclo $\omega 8 c(23.37 \%)$ and $\mathrm{C}_{16: 0}(14.83 \%)$. The contents of $\mathrm{C}_{12: 0} 3-\mathrm{OH}, \mathrm{C}_{14: 0}$, summed feature 3 $\left(\mathrm{C}_{16: 1} \omega 7 c\right.$ and/or iso $\left.\mathrm{C}_{15: 0} 2-\mathrm{OH}\right), \mathrm{C}_{10: 0}$ and $\mathrm{C}_{17: 0}$ cyclo were less than $10 \%$ (Table 2).

Tests of antimicrobial susceptibility were performed by using the disc diffusion (Kirby-Bauer) method with the antimicrobial compounds suggested by Mata et al. (2002). Results showed that strain DQD2-30 ${ }^{\mathrm{T}}$ was sensitive to (amounts per disc) cefoxitin $(30 \mu \mathrm{g})$, chloramphenicol $(30 \mu \mathrm{g})$, erythromycin $(15 \mu \mathrm{g})$, kanamycin $(30 \mu \mathrm{g})$, nalidixic acid $(30 \mu \mathrm{g})$, nitrofurantoin $(300 \mu \mathrm{g})$, polymyxin $\mathrm{B}$ (300 U), rifampicin $(5 \mu \mathrm{g})$, streptomycin $(300 \mu \mathrm{g})$ and tobramycin $(10 \mu \mathrm{g})$, but was resistant to amoxicillin $(10 \mu \mathrm{g})$, ampicillin $(10 \mu \mathrm{g})$, carbenicillin $(100 \mu \mathrm{g})$, cefotaxime $(30 \mu \mathrm{g})$, streptomycin $(10 \mu \mathrm{g})$, sulfamethoxazole $(300 \mu \mathrm{g})$ and trimethoprim-sulfamethoxazole $(1.25 \mu \mathrm{g} /$ $23.75 \mu \mathrm{g})$.

The above phenotypic, phylogenetic and genotypic results indicate that the new isolate DQD2-30 ${ }^{\mathrm{T}}$ represents a novel species of the genus Halomonas, for which the name Halomonas daqingensis sp. nov. is proposed.

\section{Description of Halomonas daqingensis sp. nov.}

Halomonas daqingensis (da.qing.en'sis. N.L. fem. adj. daqingensis pertaining to Daqing, north-eastern China, where the strain was isolated).

Cells are Gram-negative, strictly aerobic, short rods (0.7$0.8 \times 1.0-1.2 \mu \mathrm{m})$ with peritrichous flagellae. Growth occurs at temperatures between 10 and $50{ }^{\circ} \mathrm{C}$ (optimum growth at $30^{\circ} \mathrm{C}$ ), at $\mathrm{pH} 8.0-10.0$ (optimum at $\mathrm{pH} 9.0$ ) and at $\mathrm{NaCl}$ concentrations from 1 to $15 \%(\mathrm{w} / \mathrm{v})$ (optimum at 5-10\%). Gives a positive reaction in tests for oxidase, catalase and urease, for the hydrolysis of Tween 80 , casein and DNA, for aerobic nitrate or nitrite reduction and for the production of indole, EPS and $\mathrm{PHB}$, but is negative with respect to $\mathrm{H}_{2} \mathrm{~S}$ production, ONPG, activities of phenylalanine deaminase, lysine decarboxylase and ornithine decarboxylase, the methyl red and Voges- 


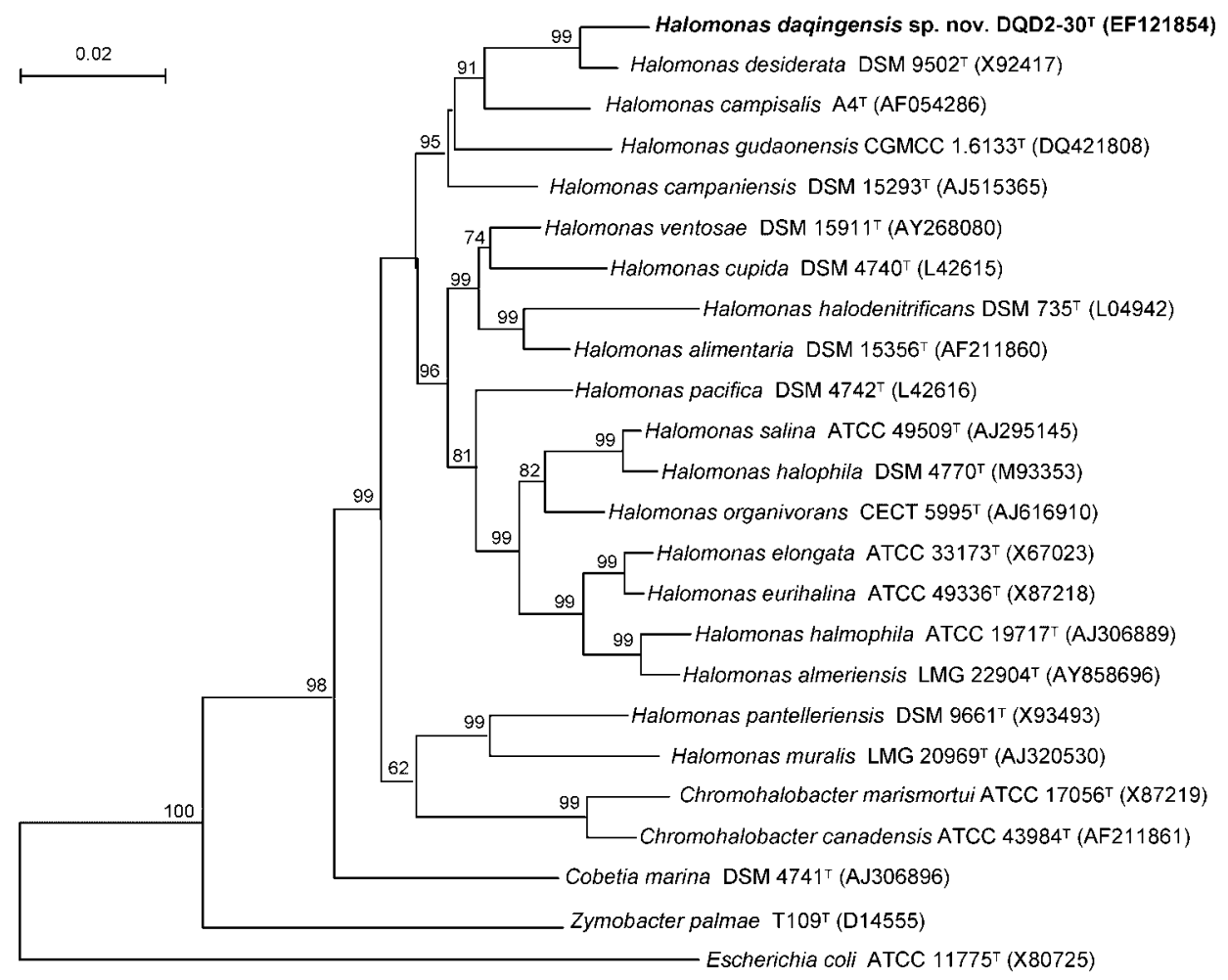

Fig. 2. Phylogenetic tree based on $16 \mathrm{~S}$ rRNA gene sequences showing the relationship between the members of the genus Halomonas and related genera within the family Halomonadaceae. Bootstrap values (\%) are based on 1000 replicates and are shown for branches with more than $50 \%$ bootstrap support. Other algorithms including maximum-parsimony and maximumlikelihood were also used to compare and determine the stability of the phylogenetic trees and gave almost the same topology as shown in this figure. Bar, 0.02 expected changes per site.

Table 2. Chemotaxonomic characteristics of strain DQD2-30 $30^{\top}$ and the related species $H$. gudaonensis, $H$. desiderata and $H$. campisalis

Taxa: 1, DQD2-30 ${ }^{\mathrm{T}} ; 2$, H. gudaonensis; 3 , H. desiderata; 4 , H. campisalis. Cells of all tested strains were grown in the same ASW medium at $30{ }^{\circ} \mathrm{C}$ for two days before harvest and further analyses. Summed features represent groups of two or three fatty acids that could not be separated by GLC with the MIDI system. Summed feature 3 contained $\mathrm{C}_{16: 1} \omega 7 c$ and/or iso $\mathrm{C}_{15: 0} 2-\mathrm{OH}$. All taxa had Q9 as the respiratory quinone.

\begin{tabular}{|lcccc|}
\hline Fatty acid & $\mathbf{1}$ & $\mathbf{2}$ & $\mathbf{3}$ & $\mathbf{4}$ \\
\hline $\mathrm{C}_{10: 0}: 0.98$ & 1.83 & 2.76 \\
Unknown 11.799 & 2.63 & 2.98 & - & - \\
$\mathrm{C}_{12: 0}$ & - & 1.25 & - & 0.86 \\
$\mathrm{C}_{12: 0}$ 3-OH & 0.85 & 8.87 & 6.27 & 5.87 \\
$\mathrm{C}_{14: 0}$ & 5.59 & - & 3.03 & 3.35 \\
Summed feature & 3.42 & 4.44 & 1.77 & 8.07 \\
$\mathrm{C}_{16: 0}$ & 2.82 & 19.66 & 18.03 & 16.44 \\
$\mathrm{C}_{17: 0}$ cyclo & 14.83 & 2.70 & 1.12 & 2.96 \\
$\mathrm{C}_{17: 0}$ & 1.08 & 0.56 & 0.42 & 0.28 \\
$\mathrm{C}_{18: 0}$ & 0.35 & 0.65 & 0.84 & - \\
$\mathrm{C}_{18: 1} \omega 7 c$ & 28.61 & 35.58 & - \\
11 methyl $\mathrm{C}_{18: 1} \omega 7 c$ & 0.56 & 0.82 & 0.78 & - \\
$\mathrm{C}_{19: 0}$ cyclo $\omega 8 c$ & 43.97 & 27.97 & 29.68 & - \\
$\mathrm{C}_{20: 2} \omega 6,9 c$ & 0.54 & 0.51 & 0.65 & - \\
Polar lipids & 23.37 & - & PG, PE, DPG & PG, PE, DPG \\
\hline
\end{tabular}


Proskauer tests and for the hydrolysis of starch and gelatin. Grows on amino acids L-proline, L-arginine, L-alanine, Lcysteine, L-histidine, L-isoleucine, L-lysine, DL-methionine, L-serine and L-valine. Utilizes D-glucose, D-mannose, Dsorbitol, maltose, sucrose, trehalose, dextrin, D-mannitol, D-gluconate, malonate, DL-malate, dextrin, D-galactose (weakly) and succinate as sole carbon sources in ASW medium without peptone and yeast extract, but it does not utilize D-fructose, D-ribose, $\alpha$-D-lactose, D-arabinose, cellobiose, L-sorbose, D-xylose, myo-inositol, salicylic acid or lactate. Produces acid from D-galactose, maltose, sucrose and trehalose, but not from adonitol, $\alpha$-D-lactose, Dmannitol, D-mannose, melezitose, L-rhamnose, D-sorbitol, D-fructose, L-sorbose, salicylic acid or myo-inositol. Sensitive to cefoxitin $(30 \mu \mathrm{g})$, chloramphenicol $(30 \mu \mathrm{g})$, erythromycin $(15 \mu \mathrm{g})$, kanamycin $(30 \mu \mathrm{g})$, nalidixic acid $(30 \mu \mathrm{g})$, nitrofurantoin $(300 \mu \mathrm{g})$, polymyxin $\mathrm{B}(300 \mathrm{U})$, rifampicin $(5 \mu \mathrm{g})$, streptomycin $(300 \mu \mathrm{g})$, tobramycin $(10 \mu \mathrm{g})$, resistant to amoxicillin $(10 \mu \mathrm{g})$, ampicillin $(10 \mu \mathrm{g})$, carbenicillin $(100 \mu \mathrm{g})$, cefotaxime $(30 \mu \mathrm{g})$, streptomycin $(10 \mu \mathrm{g})$, sulfamethoxazole $(300 \mu \mathrm{g})$ and trimethoprim-sulfamethoxazole $(1.25 \mu \mathrm{g} / 23.75 \mu \mathrm{g})$. Q9 is the only quinone and PG, DPG and PE are the predominant polar lipids. The main cellular fatty acids are $\mathrm{C}_{18: 1} \omega 7 c, \mathrm{C}_{19: 0}$ cyclo $\omega 8 c$ and $\mathrm{C}_{16: 0}$.

The type strain, DQD2-30 ${ }^{\mathrm{T}} \quad\left(=\mathrm{CGMCC} \quad 1.6443^{\mathrm{T}}=\mathrm{LMG}\right.$ $23896^{\mathrm{T}}$ ), was isolated from a soil sample contaminated with crude oil from the Daqing oilfield, Heilonjiang Province, China. The DNA G + C content of the type strain is $67.0 \mathrm{~mol} \%$.

\section{Acknowledgements}

The type strain of $H$. campisalis was a generous gift from Dr M. R. Mormile. The authors would like to thank G.-F. Zhao, B. Guo and Y.F. Guo for their valuable help. This study was supported by National Natural Science Foundation of China (30570033) and National Basic Research Program of China (2005CB221308).

\section{References}

Barritt, M. M. (1936). The intensification of the Voges-Proskauer reaction by the addition of $\alpha$-naphthol. J Pathol Bacteriol 42, 441-454.

Berendes, F., Gottschalk, G., Heine-Dobbernack, E., Moore, E. R. B. \& Tindall, B. J. (1996). Halomonas desiderata sp. nov., a new alkaliphilic, halotolerant and denitrifying bacterium isolated from a municipal sewage works. Syst Appl Microbiol 19, 158-167.

Bouchotroch, S., Quesada, E., Del Moral, A., Llamas, I. \& Béjar, V. (2001). Halomonas maura sp. nov., a novel moderately halophilic, exopolysaccharide-producing bacterium. Int J Syst Evol Microbiol 51, $1625-1632$.

Clarke, P. H. (1953). Hydrogen sulphide production by bacteria. J Gen Microbiol 8, 397-407.

Collins, M. D., Goodfellow, M. \& Minnikin, D. E. (1980). Fatty acid isoprenoid quinine and polar lipid composition in the classification of Curtobacterium and related taxa. J Gen Microbiol 118, 29-37.

De Ley, J., Cattoir, H. \& Reynaerts, A. (1970). The quantitative measurement of DNA hybridization from renaturation rates. Eur J Biochem 12, 133-142.
Dobson, S. J. \& Franzmann, P. D. (1996). Unification of the genera Deleya (Baumann et al. 1983), Halomonas (Vreeland et al. 1980), and Halovibrio (Fendrich 1988) and the species Paracoccus halodenitrificans (Robinson and Gibbons 1952) into a single genus, Halomonas, and placement of the genus Zymobacter in the family Halomonadaceae. Int J Syst Bacteriol 46, 550-558.

Dong, X.-Z. \& Cai, M.-Y. (2001). Manual of Determinative Bacteriology, pp. 370. Peking: Science Publishing Press.

Eguchi, M., Nishikawa, T. \& Macdonald, K. (1996). Responses to stress and nutrient availability by the marine ultramicrobacterium Sphingomonas sp. strain RB2256. Appl Environ Microbiol 62, 1287-1294.

Embley, T. M. (1991). The linear PCR reaction: a simple and robust method for sequencing amplified rRNA genes. Lett Appl Microbiol 13, 171-174.

Franzmann, P. D. \& Tindall, B. J. (1990). A chemotaxonomic study of members of the family Halomonadaceae. Syst Appl Microbiol 13, 142-147.

Garcia, M. T., Mellado, E., Ostos, J. C. \& Ventosa, A. (2004). Halomonas organivorans sp. nov., a moderate halophile able to degrade aromatic compounds. Int J Syst Evol Microbiol 54, 1723-1728.

Huß, V. A. R., Festl, H. \& Schleifer, K. H. (1983). Studies on the spectrophotometric determination of DNA hybridization from renaturation rates. Syst Appl Microbiol 4, 184-192.

Johnson, J. L. (1994). Similarity analysis of DNAs. In Methods for General and Molecular Bacteriology, pp. 655-681. Edited by P. E. Gerhardt, R. G. Murray, W. A. Wood \& N. R. Krieg. Washington, DC: American Society for Microbiology Press.

Kates, M. (1986). Techniques of Lipidology, 2nd edn. Amsterdam: Elsevier.

Kaye, J. Z., Márquez, M. C., Ventosa, A. \& Baross, J. A. (2004). Halomonas neptunia sp. nov., Halomonas sulfidaeris sp. nov., Halomonas axialensis sp. nov. and Halomonas hydrothermalis sp. nov.: halophilic bacteria isolated from deep-sea hydrothermal-vent environments. Int J Syst Evol Microbiol 54, 499-511.

Komagata, K. \& Suzuki, K. (1987). Lipid and cell wall analysis in bacterial systematics. Methods Microbiol 19, 161-207.

Kumar, S., Tamura, K. \& Nei, M. (2004). MEGA3: integrated software for molecular evolutionary genetics analysis and sequence alignment briefings. Bioinformatics 5, 150-163.

Marmur, J. (1961). A procedure for the isolation of deoxyribonucleic acid from microorganisms. J Mol Biol 3, 208-218.

Martínez-Cánovas, M. J., Quesada, E., Llamas, I. \& Béjar, V. (2004a). Halomonas ventosa sp. nov., a moderately halophilic, denitrifying, exopolysaccharide-producing bacterium. Int J Syst Evol Microbiol 54, 733-737.

Martínez-Cánovas, M. J., Béjar, V., Martínez-Checa, F. \& Quesada, E. (2004b). Halomonas anticariensis sp. nov., from Fuente de Piedra, a saline-wetland wildfowl reserve in Málaga, southern Spain. Int J Syst Evol Microbiol 54, 1329-1332.

Martínez-Cánovas, M. J., Quesada, E., Martínez-Checa, F. \& Béjar, V. (2004c). A taxonomic study to establish the relationship between exopolysaccharide-producing bacterial strains living in diverse hypersaline habitats. Curr Microbiol 48, 348-353.

Martínez-Checa, F., Béjar, V., Martínez-Cánovas, M. J., Llamas, I. \& Quesada, E. (2005). Halomonas almeriensis sp. nov., a moderately halophilic, exopolysaccharide-producing bacterium from Cabo de Gata, Almería, south-east Spain. Int J Syst Evol Microbiol 55, 20072011.

Mata, J. A., Martínez-Cánovas, J., Quesada, E. \& Béjar, V. (2002). A detailed phenotypic characterisation of the type strains of Halomonas species. Syst Appl Microbiol 25, 360-375. 
Mormile, M. R., Romine, M. F., Garcia, M. T., Ventosa, A., Bailey, T. J. \& Peyton, B. M. (1999). Halomonas campisalis sp. nov., a denitrifying, moderately haloalkaliphilic bacterium. Syst Appl Microbiol 22, 551-558.

Romano, I., Nicolaus, B., Lama, L., Manca, M. C. \& Gambacorta, A. (1996). Characterization of a haloalkalophilic strictly aerobic bacterium, isolated from Pantelleria Island. Syst Appl Microbiol 19, 326-333.

Smibert, R. M. \& Krieg, N. R. (1994). Phenotypic characterization. In Methods for General and Molecular Bacteriology, pp. 607-654. Edited by P. Gerhardt, R. G. E. Murray, W. A. Wood \& N. R. Krieg. Washington, DC: American Society for Microbiology.

Vreeland, R. H., Litchfield, C. D., Martin, E. L. \& Elliot, E. (1980). Halomonas elongata, a new genus and species of extremely salttolerant bacteria. Int J Syst Bacteriol 30, 485-495.
Wang, Y.-N., Cai, H., Yu, S.-L., Wang, Z.-Y. \& Wu, X.-L. (2007). Halomonas gudaonensis sp. nov., isolated from a saline soil contaminated by crude oil. Int J Syst Evol Microbiol 57, 911915.

Williams, S. T., Goodfellow, M., Alderson, G., Wellington, E. M. H., Sneath, P. H. A. \& Sackin, M. J. (1983). Numerical classification of Streptomyces and related genera. J Gen Microbiol 129, 17431813.

Zumft, W. G. (1992). The denitrifying bacteria. In The Prokaryotes. A Handbook on the Biology of Bacteria: Ecophysiology, Isolation, Identification, Application, pp. 554-582. Edited by A. Balows, H. G. Trüper, M. Dworkin, W. Harder \& K. H. Schleifer. New York: Springer Verlag. 